\title{
Muş İlinde Özel Süt Sığırcıllğı İşletmelerinde Süt Verim Özelliklerinin Belirlenmesi
}

\author{
Galip BAKIR ${ }^{1}$ iD , Mustafa KIBBAR ${ }^{2}$ iD \\ 1,Kahramanmaraş Sütçü İmam Üniversitesi, Ziraat Fakültesi, Zootekni Bölümü, Kahramanmaraş, ${ }^{2}$ Selçuk Üniversitesi, Ziraat Fakültesi, \\ Zootekni Bölümü, Konya \\ ${ }^{1}$ https://orcid.org/0000-0002-0816-227X, ${ }^{2}$ https://orcid.org/0000-0002-1895-019X \\ $\bowtie$ : galipbakir@hotmail.com
}

\section{ÖZET}

Bu araştırma, süt sığırcılı̆̆ı işletmelerinin süt verim özelliklerine ait uygulamalarını belirlemek amacıyla, Muş İli ve 5 ilçesinde 346 işletme sahibiyle yüz yüze anket yapılarak yürütülmüştür. Işletmelerde genelde sağım elle ve günde iki kez yapılırken, sağım süresi ortalama 7.4 ay olarak bulunmuştur. Günlük ortalama süt verimi $10.3 \mathrm{~kg}$ iken, il genelinde süt verimi işletmelerin \%50.7'sinde 6-10 kg aralığında yoğunlaşmaktadır. İşletmecilerin \%59.3’ü ineklerden elde edilen sütün yeterli olmadığını ve \%86.4'ü süt veriminin mevsime göre değiştiğini belirtmiştir. İşletmelerin \%82.6'sı inekleri kuruya çıkarmakta ve \%55.8’i 60 gün kuruda tutmaktadır. İşletmelerin \%54'ünün sağım öncesi meme temizliği yaptığı ve \%32.2'sinin sağım sonrası daldırma işlemi yaptığı belirlenmiştir. Üretilen süt işletmelerin \%70.5'inde "peynir-yoğurt-tereyağı" kombinasyonu şeklinde ürüne dönüştürülmektedir. Hayvan sayısı az olan işletmelerde üretilen sütün tamamı ev ihtiyacı için tüketilirken, diğer işletmelerde ise genellikle sütün \%10-15’i tüketilmektedir İşletmelerde süt verimini artırmak için, barınak dâhil alt yapısının iyileştirilmesi, yetiştirilen ırklar içinde kültür ırklarının oranının artırılması, mera imkânı ve mera ot kalitesinin artırılması gerekmektedir. Bunlarla birlikte hayvancılığın sadece meraya dayalı yapılmaması ile yetiştiricilerin teknik bilgi düzeylerinin artırılması gibi bir takım tedbirlerin alınması önerilmektedir.

\section{Determination of Milk Yield Characteristics in Private Dairy Cattle Farms in Muş Province}

\section{ABSTRACT}

Objective of this study was to determine the application of dairy cattle breeding practices 346 farm located in Muş province and its 5 districts. While milking was performed by hand twice a day in farms, milking period average was found to be about 7.4 months. While the average daily milk yield was $10.3 \mathrm{~kg}$, milk yield in the province was concentrated in the range of $6-10 \mathrm{~kg}$ in $50.7 \%$. Overall, $59.3 \%$ of the operators stated that the milk obtained from the cows was not sufficient and $86.4 \%$ of them stated that the milk yield varied seasonally. Generally, $82.6 \%$ of the farms dried the cows and $55.8 \%$ kept 60 days in dry period. Additionally, 54\% of the farms had teat cleaning before milking and after the milking, the rate of those who had immersion was found to be $32.2 \%$. Additionally, $70.5 \%$ of the farms converted the produced milk into the form of cheese-yoghurtbutter products. The total milk produced in farms with a small number of animals was consumed for household needs, in others, 10$15 \%$ was generally consumed for the same purpose. In order to increase milk yield in the farms, measures such as improving the infrastructure of the enterprise including shelter, increasing the rate of culture races in the breeds, increasing the quality of pasture and increasing the technical knowledge of breeders were recommended.

\section{Araştırma Makalesi}

Makale Tarihçesi
Geliş Tarihi $\quad: 11.02 .2018$
Kabul Tarihi $\quad: 28.03 .2019$

Anahtar Kelimeler

Süt verim özellikleri

Süt sığırcılığı işletmeleri

Muş

\section{Research Article}

$\begin{array}{ll}\text { Article History } & \\ \text { Received } & : 11.02 .2018 \\ \text { Accepted } & : 28.03 .2019\end{array}$

\section{Keywords}

Milk yield characteristics

Dairy cattle farms

Muş province. 


\section{GİRIŞ}

Türkiye'de hayvancılık sektörünün önemli bir kolu olan süt sığırcılığı ülke kalkınmasına farklı açılardan katkıda bulunmaktadır. Öncelikle tüketiciler açısından ele alındığında, yeterli ve dengeli beslenmeyi amaçlayan her insanın günlük diyetinde belirli oranda süt ve süt ürünlerinin bulunması gerekmektedir. Dünyada süt ve süt ürünleri tüketimi aynı zamanda ülkeler arasında bir gelişmişlik göstergesi olarak kabul edilmekte, gelişmiş ülkelerdeki tüketim gelişmekte olan ülkelere göre daha yüksek miktarlarda gerçekleşmektedir (Boz, 2013).

Üreticiler açısından ele alındığında Türkiye'de kırsal alanda yaşayan nüfusun önemli bir kısmı geçimini hayvancılık faaliyetlerinden sağlamaktadır. Süt sığırcılığı hem birkaç süt ineği ile beraber küçük aile işletmeleri şeklinde hem de özellikle nüfusu büyük olan illere yakın alanlarda büyük ticari işletmeler halinde yapılmaktadır. Süt sığırcılı̆̆ının yerel, bölgesel ve ülkesel olarak ekonomiye olan katkısının artırılması için mevcut sorunlarının giderilmesi gerekir. Sorunlar belirlendikten sonra çeşitli politika ve stratejilerle sektörü geliştirmek ve çeşitli düzeylerde ekonomiye olan katkısını artırmak için çalışmalar yapılabilir (Boz, 2013).

$\mathrm{Bu}$ konuda ülkenin değişik illerinde sığırcılık faaliyetiyle uğraşan yetiştiricilerin sosyo-demografik özelliklerini, bir kısım tercihlerini, sahada karşılaştıkları başlıca sorunları ve yetkililerden beklentilerinin tespitine ve işletmelerin mevcut yapısal durumlarının ortaya konulmasına yönelik günümüze kadar yapılmış birçok çalışma bulunmaktadır (Kum, 2006; Tatar, 2007; Önal ve Özder, 2008; Tugay ve Bakır, 2009; Demir ve Aral, 2009; Şeker ve ark., 2012; Çoban ve ark., 2013; Tutkun ve ark., 2014; Daş ve ark., 2014; Güler ve ark., 2016; Bakan ve Aydın, 2016; Koçyiğit ve ark., 2017). Bu tip çalışmaların daha kapsamlı ve belirli zaman aralıklarında tekrarı, sahadaki durumun güncellenmesi, zaman içerisindeki değişimlerin takibi ve bu sayede sorunların çözümü noktasında önem arz etmektedir. Bu tip çalışmalar sayesinde sığırcılık işletmelerindeki sorunların belirlenmesi ve gerekli çözümlerin ortaya konulması mümkün olabilecektir.

Doğu Anadolu Bölgesinde bulunan Muş ilinin yüzölçümü, Türkiye yüzölçümünün \%1.1'ini kaplamakta ve ilde ekonomik yapı temelde tarım ve hayvancılığa dayalıdır. İlde hayvancılık, çoğunlukla meraya dayalı olarak yapılmakta ve büyükbaş hayvan varlığı Türkiye'deki büyükbaş hayvanların yaklaşık \%2'sini oluşturmaktadır. Yörede hayvancılık büyük ölçüde geleneksel yöntemlerle yapıldığı için hayvan başına alınan veriminde düşük olduğu bildirilmektedir (Şeker ve ark., 2012). İlde 2018 yılı verilerine göre, 299.518 büyükbaş hayvan (manda hariç) bulunmakta ve bunların \%34'ü yerli ırk, \%42'si melez, \%22'si kültür ırkından meydana gelmektedir (Anonim, 2019).

Muş ilindeki işletmelerde süt verim özellikleri ile ilgili, Şeker ve ark. (2012)'nın yaptıkları çalışmada, yetiştiricilerin \%46.0'sının ineklerini sütten kendiliğinden kesilene kadar sağdıklarını, \%38.7'sinin de doğumuna 2 ay kala ineklerini kuruya çıkardıklarını bildirmişlerdir. İşletmelerde inek başına ortalama günlük süt verimini $<3.0 \mathrm{~kg}(\% 24.8)$, $3.0-5.0 \mathrm{~kg}(\% 30.4), 5.1-7.0 \mathrm{~kg}(\% 23.2)$ ve günlük ortalama $15 \mathrm{~kg}$ ve daha fazla süt elde edenlerin oranını ise sadece \%3.2 olarak bildirmişlerdir. Ayrıca, işletmelerin \%78.4'ünün $7 \mathrm{~kg}$ ve daha az günlük ortalama süt verimine sahip olmasında, yetiştiricilerin elinde bulunan sığırların yaklaşık \%47'sinin yerli ırk olmasının yanında işletmelerde karlı ve başarılı sı̆̆ır yetiştiriciliği için bakım ve besleme koşullarının oldukça yetersiz olmasının da payı olduğunu bildirmişlerdir.

Bu bağlamda, Muş İlinde 2009-2010 yılında dar kapsamlı benzer bir çalışma yapılmıştır. Bu çalışma önceki Şeker ve ark. (2012) tarafindan yapılan çalışmadan hem daha kapsamlı hem de son zamanlarda uygulanan bir takım teşvik programlarının sonrasını kapsamaktadır. Bu çalışma Muş ilindeki süt sığırcılığı işletmelerinin süt verim özellikleri, sütün ürünlere dönüşümü, süt veriminin değişimi ve sağım uygulamalarının mevcut durumunu belirlemek amacıyla yapılmıştır.

\section{MATERYAL ve METOT}

Araştırma materyalini, Muş ili merkez ve ilçelerinde (Malazgirt, Bulanık, Hasköy, Korkut ve Varto) bulunan büyükbaş hayvancılık işletmelerinde yüz yüze yapilan anket verileri oluşturmuştur. Araştırmada, büyükbaş hayvan varlığı bakımından ilçeleri temsil eden köyler, bölgede görev yapan teknik elemanların görüşü alınarak belirlenmiştir. Muş İ Tarım ve Orman Müdürlüğü 2017 yılı kayıtlarından alınan toplam işletme sayısı dikkate alınarak, 346 $(\% 3,3)$ işletme şansa bağlı olarak belirlenmiştir. İşletme sayısının belirlenmesinde Yamane (2006) örnek hacminin en az \%3’ünün veya Cochran (1977) \%10'unun alınmasının yeterli olacağı ilkesi dikkate alınmıştır. Verilerin analizlerinde SPSS 21.0 paket programı kullanılarak, çapraz tablolar oluşturulmuş ve faktörlerin etkilerini belirlemek için ki kare önemlilik testi (Düzgüneş ve ark., 1983) yapılmış ve bazı özelliklere ait ortalama frekans değerleri verilmiştir.

\section{BULGULAR ve TARTIŞMA}

İşletmelerde yetiştirilen inekler yerli, melez ve kültür ırklarından oluşurken ve tüm sığır varlığı içinde, ırkların frekans değerlerine göre dağılımı sırasıyla 
$\% 50.2$, \%27.4 ve \%22.4 olarak bulunmuştur. İşletmelerin kiminde tek ırk, kiminde ise iki veya üç ırkın birlikte yetiştirildiği belirlenmiştir. Buna göre, işletmelerde tek olarak en çok yetiştirilen 1 rk \%35.5 oraniyla melezler olurken, bunu \%22 oraniyla yerli+melez ırk ikilisi izlemektedir (Çizelge 1). Mevki bazında ise, Merkez, Malazgirt, Hasköy ve Varto ilçelerinde en çok yetiştirilen ırk melez olarak bulunmuştur. Kültür ırkının en fazla (\%62.5) yetiştirildiği ilçe Korkut olurken, bunu Hasköy (\%38.9), Merkez (\%17) ve Varto (\%17.9) ilçeleri izlemektedir. Bulanık kültür ırkının en az, ancak yerli+melez kombinasyonunun en fazla yetiştirildiği ilçe konumunda iken, Varto ise melez irkın en fazla yetiştirildiği ilçe olarak bulunmuştur. Mevki ile mevcut ırklar arasındaki ilişki çok önemli $(\mathrm{p}<0.01)$ bulunmuştur.

Çizelge 1. Mevcut ırkların mevkiye göre dağılımı

\begin{tabular}{|c|c|c|c|c|c|c|c|c|}
\hline \multirow[b]{2}{*}{ Mevki } & & \multicolumn{6}{|c|}{ Mevcut irklar** } & \multirow[b]{2}{*}{ Toplam } \\
\hline & & Yerli & Kültür & Melez & Yerli+melez & Kültür+melez & Yerli+kültür+melez & \\
\hline \multirow{2}{*}{ Merkez } & Adet & 2 & 9 & 26 & 6 & 8 & 2 & 53 \\
\hline & $\%$ & 3.8 & 17.0 & 49.1 & 11.3 & 15.1 & 3.8 & 100.0 \\
\hline \multirow{2}{*}{ Malazgirt } & Adet & 10 & 7 & 34 & 8 & 0 & 23 & 82 \\
\hline & $\%$ & 12.2 & 8.5 & 41.5 & 9.8 & 0.0 & 28.0 & 100.0 \\
\hline \multirow{2}{*}{ Bulanık } & Adet & 9 & 5 & 15 & 55 & 5 & 19 & 108 \\
\hline & $\%$ & 8.3 & 4.6 & 13.9 & 50.9 & 4.6 & 17.6 & 100.0 \\
\hline \multirow{2}{*}{ Hasköy } & Adet & 1 & 7 & 8 & 0 & 0 & 2 & 18 \\
\hline & $\%$ & 5.6 & 38.9 & 44.4 & 0.0 & 0.0 & 11.1 & 100.0 \\
\hline \multirow{2}{*}{ Korkut } & Adet & 0 & 15 & 3 & 0 & 5 & 1 & 24 \\
\hline & $\%$ & 0.0 & 62.5 & 12.5 & 0.0 & 20.8 & 4.2 & 100.0 \\
\hline \multirow{2}{*}{ Varto } & Adet & 2 & 10 & 35 & 6 & 3 & 0 & 56 \\
\hline & $\%$ & 3.6 & 17.9 & 62.5 & 10.7 & 5.4 & 0.0 & 100.0 \\
\hline \multirow{2}{*}{ Toplam } & Adet & 24 & 53 & 121 & 75 & 21 & 47 & 341 \\
\hline & $\%$ & 7.0 & 15.5 & 35.5 & 22.0 & 6.2 & 13.8 & 100.0 \\
\hline
\end{tabular}

$* * \mathrm{p}<0.01$

Muş ilinde yapılan araştırmada, işletmelerde bulunan sığırların ırk dağılımı \%46.9 yerli, \%37.2 melez ve \%15.9 kültür olarak bildirilmiştir. İşletmelerde kültür ırkı sığırların dağılımı Esmer (\%70.3), Simental (\%17.2) ve Siyah Alaca ırkı (\%12.5) şeklinde bildirilmiştir (Şeker ve ark., 2012). Araştırmacılar, Muş ilinin de içinde bulunduğu Doğu Anadolu Bölgesinin karasal iklime sahip olmasina atıfta bulunarak, bu iklim şartlarına uygun ve diğer ırklardan daha dayanıklı olan ve kültür ırkları içerisinde de hastalıklara karşı daha dirençli olarak bilinen Esmer ve Simental ırklarının tercih edilmiş olmasının önemli olduğunu bildirmektedir. Aynı araştırmacılar, il genelindeki işletmelerde yetiştirilen kültür ırkı sayısında artış olduğunu ve bu durumun süt sığırcılığını destekleme çalışmalarının işletmelere olumlu etki gösterdiğini bildirmektedirler.

Bu çalışmada yerli ırka ait bulunan değer (\%50.2) Muş ilinde yapılan önceki çalışma değeriyle uyum halindedir. Bu durum, il genelindeki işletmelerde yerli ırkın hâkimiyetini koruduğunu ortaya koymaktadır. Yörede yerli ırkın yoğun olması, işletmelerin \%50'sinde hayvan sayısı 20 baş olduğu göz önüne alınırsa hayvancılığın küçük aile işletmeciliği halinde yapıldığı ve bölgenin iklim şartlarından kaynaklandığı düşünülmektedir. Ayrıca, işletmelerde melez ırkın mevcudiyetinde düşüş ve kültür ırkının ise \%15.9'dan \%22.4'e yükseldiği belirlenmiştir. Doğu Anadolu Bölgesinde, çeşitli illerde yapılan çalışmalarda çoğunlukla melez ve yerli sığırların tercih edildiğinin (Öztürk ve Karkacıer, 2008; Çoban ve ark., 2013; Tilki ve ark. 2013) bildirilmesi, mevcut durumu desteklemektedir.

Araştırmadan farklı olarak Daş ve ark. (2014), Bingöl'de (\%50.9), Güler ve ark. (2016) Hınıs ilçesinde (\%77.2) melez ırkların ve Bakan ve Aydın (2016) Ağrı'da ise kültür ırkının yaygın olarak yetiştirildiğini bildirmişlerdir. Ayrıca, Güler ve ark. (2016)'ı Hınıs ilçesinde melez sığırların fazla olmasını, ilçede yerli ırkların ıslahında önemli bir ilerleme olduğunun işareti olarak görüldüğünü bildirmektedirler.

İşletmelerde sağım süresi ortalama 7.4 ay iken 4 -11 ay aralığında değişim göstermektedir. İl genelinde sağım süresi en fazla \%33.4 oranıyla 8-9 ay aralığında iken, 5 aydan az sağılan ineklerin oranı \%14.6 ve 10 aydan fazla sağılan ineklerin oranı ise \%20.9 ay olarak bulunmuştur (Çizelge 2). Mevki bazında ise, Merkez ve Hasköy ilçelerinde en fazla sağım süresi 6-9 aydır. Korkut'ta en fazla kültür ırkının yetiştirilmesi nedeniyle ineklerin \%83.3'ünün 10 aydan fazla sağılması, kültür ırkı karakterine uygun bulunmuştur. Hasköy ilçesindeki işletmelerde kültür ve melez ırk yoğunluğu olmasına rağmen, sağım süresinin 10 ay ve üzeri olan işletme sayısının \%5.6 olması dikkat çekici bulunmuştur. Bu durumun barınak, bakım ve besleme yetersizliğinden kaynaklanmış olabileceği düşünülmektedir. Mevki ile sağım süresi arasındaki ilişki çok önemli $(p<0.01)$ 
bulunmuştur.

Kars ilinde yetiştirilen ineklerin ortalama laktasyon süresi 6 ay olarak tespit edilmiştir (Demir ve Aral, 2009). Erzurum ili Narman ilçesindeki işletmelerde sağım süresi 8 ay (\%24), 9 ay (\%40.9) ve 10 ay (\%24.5) olarak belirlenmiştir. Yani, yörede işletmelerin \%75.5'inde hayvanların 10 aydan daha az sürede sağıldıkları belirlenmiştir (Koçyiğit ve ark., 2017). Bu araştırmada bulunan değer Kars ilinde bulunan değerden yüksek ve Narman ilçesinde bulunan değerlerden düşük bulunmuştur. Laktasyon süresinin ideal sürenin altında olması Koçyiğit ve ark. (2017)'nın da belirttiği gibi yerli ve melez sığırların yoğunlukta olması, yetersiz barınak şartları ile bakım ve besleme uygulamalarına maruz kalmalarına bağlanabilir.

İ genelinde günlük ve yıllık süt verimi frekans değerlerine göre, ortalama $10.3 \mathrm{~kg}$ ve $2423.8 \mathrm{~kg}$ olup, günlük süt verimi 5-26 kg ve yıllık süt verimi 608-7904 kg aralığında değişmektedir. Yine il genelinde günlük süt verim ortalaması en fazla $(\% 50.7) \quad 6-10 \quad \mathrm{~kg}$ grubunda bulunmuştur (Çizelge 3). Mevki bazında ise, Malazgirt, Bulanık, Hasköy ve Varto ilçelerinde en fazla süt verimi 6-10 kg grubunda iken, kültür ırkının en fazla bulunduğu Korkut ilçesinde ise $11-15 \mathrm{~kg}$ grubunda olması anlamlı bulunmuştur. Günlük $16 \mathrm{~kg}$ ve üzeri süt alınan işletmelerin en fazla \%25 oranıyla Korkut ilçesinde bulunması da, ilçede kültür ırkı sığır yoğunluğu açısından anlamlı bulunmuştur. Mevki ile günlük süt verimi arasındaki ilişki önemli $(\mathrm{p}<0.05)$ bulunmuştur.

İl genelinde yıllık süt verimi \%53.8 oranıyla 2000-3000 $\mathrm{kg}$ arasında yoğunlaşmaktadır.

Çizelge 2. İneklerin sağım süresinin mevkiye göre değişimi

\begin{tabular}{|c|c|c|c|c|c|c|}
\hline \multirow{2}{*}{ Mevki } & & \multicolumn{4}{|c|}{ Sağım süresi (ay)** } & \multirow{2}{*}{ Toplam } \\
\hline & & $5 \geq$ & $6-7$ & 8-9 & $10 \leq$ & \\
\hline \multirow{2}{*}{ Merkez } & Adet & 2 & 23 & 23 & 4 & 52 \\
\hline & $\%$ & 3.8 & 44.2 & 44.2 & 7.7 & 100.0 \\
\hline \multirow{2}{*}{ Malazgirt } & Adet & 18 & 16 & 29 & 19 & 82 \\
\hline & $\%$ & 22.0 & 19.5 & 35.4 & 23.2 & 100.0 \\
\hline \multirow{2}{*}{ Bulanık } & Adet & 22 & 33 & 32 & 17 & 104 \\
\hline & $\%$ & 21.2 & 31.7 & 30.8 & 16.3 & 100.0 \\
\hline \multirow{2}{*}{ Hasköy } & Adet & 0 & 9 & 8 & 1 & 18 \\
\hline & $\%$ & 0.0 & 50.0 & 44.4 & 5.6 & 100.0 \\
\hline \multirow{2}{*}{ Korkut } & Adet & 0 & 1 & 3 & 20 & 24 \\
\hline & $\%$ & 0.0 & 4.2 & 12.5 & 83.3 & 100.0 \\
\hline \multirow{2}{*}{ Varto } & Adet & 7 & 22 & 17 & 9 & 55 \\
\hline & $\%$ & 12.7 & 40.0 & 30.9 & 16.4 & 100.0 \\
\hline \multirow{2}{*}{ Toplam } & Adet & 49 & 104 & 112 & 70 & 335 \\
\hline & $\%$ & 14.6 & 31.0 & 33.4 & 20.9 & 100.0 \\
\hline
\end{tabular}

$* * \mathrm{p}<0.01$

Ciizelge 3. Günlük ve ylllık süt veriminin mevkiye göre değişimi

\begin{tabular}{|c|c|c|c|c|c|c|c|c|c|c|c|c|}
\hline \multirow{2}{*}{ Mevki } & & \multicolumn{4}{|c|}{ Günlük süt verimi $(\mathrm{kg})$ * } & \multirow[b]{2}{*}{ Toplam } & \multicolumn{5}{|c|}{ Yillık süt verimi $(\mathrm{kg}) * *$} & \multirow[b]{2}{*}{ Toplam } \\
\hline & & $<5$ & $6-10$ & $11-15$ & $16>$ & & 1000 & $1-2000$ & $2001-30$ & $\begin{array}{l}3001^{-} \\
4000\end{array}$ & $4001+$ & \\
\hline \multirow{2}{*}{ Merkez } & Sayı & 5 & 21 & 19 & 9 & 54 & 4 & 9 & 20 & 6 & 13 & 52 \\
\hline & $\%$ & 9.3 & 38.9 & 35.2 & 16.7 & 100.0 & 7.7 & 17.3 & 38.5 & 11.5 & 25.0 & 100.0 \\
\hline \multirow{2}{*}{ Malazgirt } & Sayı & 7 & 46 & 21 & 8 & 82 & 12 & 17 & 20 & 20 & 13 & 82 \\
\hline & $\%$ & 8.5 & 56.1 & 25.6 & 9.8 & 100.0 & 14.6 & 20.7 & 24.4 & 24.4 & 15.9 & 100.0 \\
\hline \multirow{2}{*}{ Bulanık } & Sayı & 16 & 60 & 25 & 3 & 104 & 14 & 31 & 30 & 17 & 11 & 103 \\
\hline & $\%$ & 15.4 & 57.7 & 24.0 & 2.9 & 100.0 & 13.6 & 30.1 & 29.1 & 16.5 & 10.7 & 100.0 \\
\hline \multirow{2}{*}{ Hasköy } & Sayı & 2 & 9 & 4 & 3 & 18 & 1 & 5 & 5 & 5 & 2 & 18 \\
\hline & $\%$ & 11.1 & 50.0 & 22.2 & 16.7 & 100.0 & 5.6 & 27.8 & 27.8 & 27.8 & 11.1 & 100.0 \\
\hline \multirow{2}{*}{ Korkut } & Sayı & 0 & 7 & 11 & 6 & 24 & 0 & 0 & 2 & 4 & 18 & 24 \\
\hline & $\%$ & 0.0 & 29.2 & 45.8 & 25.0 & 100.0 & 0.0 & 0.0 & 8.3 & 16.7 & 75.0 & 100.0 \\
\hline \multirow{2}{*}{ Varto } & Sayı & 7 & 28 & 15 & 5 & 55 & 1 & 22 & 9 & 11 & 12 & 55 \\
\hline & $\%$ & 12.7 & 50.9 & 27.3 & 9.1 & 100.0 & 1.8 & 40.0 & 16.4 & 20.0 & 21.8 & 100.0 \\
\hline \multirow{2}{*}{ Toplam } & Sayı & 37 & 171 & 95 & 34 & 337 & 32 & 84 & 86 & 63 & 69 & 334 \\
\hline & $\%$ & 11.0 & 50.7 & 28.2 & 10.1 & 100.0 & 9.6 & 25.1 & 25.7 & 18.9 & 20.7 & 100.0 \\
\hline
\end{tabular}

$* \mathrm{p}<0.05 * * \mathrm{p}<0.01$ 
İlçe bazında incelendiğinde, kültür ırkının yoğun yetiştirildiği Korkut ilçesinde $2000 \mathrm{~kg}$ dan az süt alınan işletme bulunmazken, ilçede bulunan işletmelerin \%75.6'sının $4000 \mathrm{~kg}$ üzeri süt verdiği tespit edilmiştir. Melez ırkın yoğun yetiştirildiği Varto ilçesindeki işletmelerin yıllık süt verimi $1001-2000 \mathrm{~kg}$ arasında (\%40) yoğunlaşmaktadır. Bu durum, ilçedeki işletmelerde bakım, besleme ve barınak şartlarında sorun olduğunu düşündürmektedir. İl genelinde 1000 kg'dan az süt alınan işletmeler yerli irkın en yoğun yetiştirildiği Malazgirt ve $4000 \mathrm{~kg}$ ve üzeri en az süt alınan işletmelerin Bulanık ilçelerinde yoğunlaştığ görülmektedir. Mevki ile yıllık süt verimi arasındaki ilişki çok önemli $(\mathrm{p}<0.01)$ bulunmuştur.

Muş ilinde daha önce Şeker ve ark.,(2012)'ı tarafından yapılan araştırmada yetiştiricilerin, inek başına ortalama günlük süt verimini $<3.0 \mathrm{~kg}(\% 24.8), 3.0-5.0$ $\mathrm{kg}(\% 30.4), 5.1-7.0 \mathrm{~kg}$ (\%23.2) olarak bildirmişlerdir. İşletmelerin \%78.4'ünün $7 \mathrm{~kg}$ ve daha az günlük ortalama süt verimine sahipken, günlük ortalama 15 $\mathrm{kg}$ ve daha fazla süt alan işletmelerin oranının ise sadece \%3.2 olduğu tespit edilmiştir. Araştırıcılar, bu sonucun elde edilmesinde, yetiştiricilerin elinde bulunan sığırların yaklaşık \%47'sinin yerli ırk olması yanında, işletmelerde karlı ve başarılı sığır yetiştiriciliği için bakım ve beslemenin yetersiz olmasının da payı olduğunu bildirmektedirler. Araştırmacıların sonuçları, bu araştırmayla kıyaslandığında, süt veriminde azda olsa bir artış olduğu görülmektedir. Bu durum, işletmelerde kültür ırkı sayısındaki artışa bağlanabilir.

Benzer çalışmalarda günlük süt verimi Tekirdağ ilinde (Önal ve Özder, 2008) hayvanların \%43.9'unun $20 \mathrm{lt}$, $\% 45.6$ 'sinin 25 lt ve \%8.8'inin 15 lt olarak bulunurken, Giresun'da (Tugay ve Bakır, 2009) işletmelerin \%90.9'unda 3-7 $\mathrm{kg}$ arasında süt alındığ bildirilmektedir. Savaş ve Yenice (2016) Rize ilindeki işletmelerin \%80.5’nin ortalama günlük süt veriminin 10 litreden az, \%7.4'nin ise 20 litreden az olduğunu belirlemiştir. $\mathrm{Bu}$ araştırmada bulunan günlük süt verimi değeri Önal ve Özder (2008)'in bildirdiği değerlerden düşük, Tugay ve Bakır (2009)'ın bildirdiği değerden daha yüksek bulunmuştur.

İ genelinde işletmelerin \%40.7'sinde ineklerden alınan süt veriminin yeterli olduğu ve $\% 59.3$ 'ünde ise ineklerden alınan süt veriminin yeterli olmadığı belirlenmiştir (Çizelge 4).

İlçe bazında ise, süt veriminin yeterli olduğunu ifade eden işletmelerin oranı melez ve kültür ırkın yoğun yetiştirildiği il merkezinde $\% 51.9$ ve Korkut ilçesinde \%91.7 olarak bulunmuştur. Buna karşın, melez ve yerli ırkın yoğun yetiştirildiği Malazgirt, Hasköy, Bulanık ve Varto ilçelerinde bulunan işletmelerde süt veriminin yüksek oranlarda yeterli olmadığı tespit edilmiştir. İşletmelerde süt veriminin yeterli ve yetersiz olmasında yetiştirilen ırkın önemli etkisinin olduğu belirlenmiştir. Mevki ile süt veriminin yeterliliği arasındaki ilişki çok önemli $\quad(p<0.01)$ bulunmuştur.

İneklerden alınan süt veriminin yetersiz olarak belirtilmesine sebep olarak, anket yapılan 346 işletmenin 185 'inde yetiştirilen rrkın, 110'nunda barınak şartlarının ve 249'unda bakım beslemenin yetersiz olması bulunmuştur.

Çizelge 4'de görüldüğü gibi, işletmeciler süt veriminin yetersizliğinde, bu üç faktörün ikili ya da üçlü kombinasyonları farklı oranlarda bulunmuştur. Buna göre, il genelinde barınak-bakım besleme, ırk-bakım besleme ve irk-barınak-bakım beslemeye ait oranlar sirasıyla \%14.5, \%24 ve \%22.6 olarak bulunmuştur.

Çizelge 4. Süt veriminin yeterliliği ve verim az ise nedeninin mevkiye göre değişimi

\begin{tabular}{|c|c|c|c|c|c|c|c|c|c|c|}
\hline \multirow[b]{2}{*}{ Mevki } & & \multicolumn{3}{|c|}{ Verim yeterli mi?** } & \multicolumn{6}{|c|}{ Süt verimi az ise nedeni** } \\
\hline & & Evet & Hayır & Toplam & Irk & $\begin{array}{l}\text { Bakım } \\
\text { besleme }\end{array}$ & $\begin{array}{l}\text { Irk- bakım } \\
\text { besleme }\end{array}$ & $\begin{array}{l}\text { Barınak- } \\
\text { bakım bes. }\end{array}$ & $\begin{array}{l}\text { Irk-barınak- } \\
\text { bakım bes. }\end{array}$ & Toplam \\
\hline \multirow{2}{*}{ Merkez } & Adet & 28 & 26 & 54 & 9 & 13 & 10 & 5 & 4 & 41 \\
\hline & $\%$ & 51.9 & 48.1 & 100.0 & 22.0 & 31.7 & 24.4 & 12.2 & 9.8 & 100.0 \\
\hline \multirow{2}{*}{ Malazgirt } & Adet & 31 & 51 & 82 & 10 & 15 & 9 & 12 & 27 & 73 \\
\hline & $\%$ & 37.8 & 62.2 & 100.0 & 13.7 & 20.5 & 12.3 & 16.4 & 37.0 & 100.0 \\
\hline \multirow{2}{*}{ Bulanık } & Adet & 30 & 74 & 104 & 11 & 20 & 27 & 6 & 33 & 97 \\
\hline & $\%$ & 28.8 & 71.2 & 100.0 & 11.3 & 20.6 & 27.8 & 6.2 & 34.0 & 100.0 \\
\hline \multirow{2}{*}{ Hasköy } & Adet & 7 & 11 & 18 & 1 & 5 & 4 & 3 & 1 & 14 \\
\hline & $\%$ & 38.9 & 61.1 & 100.0 & 7.1 & 35.7 & 28.6 & 21.4 & 7.1 & 100.0 \\
\hline \multirow{2}{*}{ Korkut } & Adet & 22 & 2 & 24 & 1 & 8 & 3 & 10 & 0 & 22 \\
\hline & $\%$ & 91.7 & 8.3 & 100.0 & 4.5 & 36.4 & 13.6 & 45.5 & 0.0 & 100.0 \\
\hline \multirow{2}{*}{ Varto } & Adet & 19 & 36 & 55 & 15 & 7 & 18 & 7 & 2 & 49 \\
\hline & $\%$ & 34.5 & 65.5 & 100.0 & 30.6 & 14.3 & 36.7 & 14.3 & 4.1 & 100.0 \\
\hline \multirow{2}{*}{ Toplam } & Adet & 137 & 200 & 337 & 47 & 68 & 71 & 43 & 67 & 296 \\
\hline & $\%$ & 40.7 & 59.3 & 100.0 & 15.9 & 23.0 & 24.0 & 14.5 & 22.6 & 100.0 \\
\hline
\end{tabular}

$* * \mathrm{p}<0.01$ 
Mevki bazında incelendiğinde, kültür ırkının yoğun yetiştirildiği Korkut ve Varto ilçelerinde süt veriminin yetersizliğinde bakım beslemenin yanında barınakbakım besleme kombinasyonunun önemli etken olduğu belirlenmiştir. Ayrıca, Varto ilçesinde ırk, süt verimini \%30.6 oranında olumsuz etkileyen tek faktör olarak bulunmuştur. Melez ve yerli ırkın yoğun yetiştirildiği işletmelerde süt veriminin yetersizliğinde ırk faktörünün yanında bakım besleme ve barınak şartlarının da önemli bir faktör olduğu tespit edilmiştir. Mevki ile süt veriminin yetersizlik nedenleri arasındaki ilişki çok önemli $\quad(p<0.01)$ bulunmuştur.

İşletmelerde süt veriminin mevsim şartlarına göre \%86.4 oranında değişim gösterdiği tespit edilmiştir. Mevsim olarak ilkbaharın taze otların çıkması nedeniyle süt verimini olumlu, yazın otların sararması ve sıcaklık stresi nedeniyle olumsuz etkilediği belirlenmiştir. Buna ilaveten meraların alan ve ot kalitesi bakımından yetersizliği ile kesif yemin kalite ve fiyatının da süt verimine önemli etkisinin olduğu düşünülmektedir (Çizelge 5). Mevki ile süt veriminin mevsime göre değişimi arasındaki ilişki çok önemli $(\mathrm{p}<0.01)$ bulunmuştur.

Süt veriminin mevsime göre değişim göstermediğini ifade eden işletmelerin Malazgirt ve Bulanık ilçesinde en fazla olması, işletmelerde yoğun olarak melez ve yerli ırkların yetiştirilmesinden ileri geldiği düşünülmektedir. Buna karşın, kültür ırkının yoğun olarak yetiştirildiği Korkut ilçesinde ise, işletmelerin tamamında süt veriminin mevsime göre değişim gösterdiği belirlenmiştir (Çizelge 5). Mevki ile arasındaki ilişki çok önemli $(\mathrm{p}<0.01)$ bulunmuştur.

Çizelge 5. Süt veriminin mevsime ve nedeninin mevkiye göre değişimi

\begin{tabular}{|c|c|c|c|c|c|c|c|c|c|}
\hline \multirow{2}{*}{ Mevki } & & \multicolumn{3}{|c|}{ Mevsime göre değişim ** } & \multicolumn{5}{|c|}{ Mevsime göre değişim nedeni** } \\
\hline & & Evet & Hayır & Toplam & İlkbahar & Yaz & Mera etkisi & Yem & Toplam \\
\hline \multirow{2}{*}{ Merkez } & Adet & 51 & 1 & 52 & - & - & - & - & - \\
\hline & $\%$ & 98.1 & 1.9 & 100 & - & - & - & - & - \\
\hline \multirow{2}{*}{ Malazgirt } & Adet & 64 & 17 & 81 & 6 & 0 & 0 & 0 & 6 \\
\hline & $\%$ & 79 & 21 & 100 & 100 & 0 & 0 & 0 & 100 \\
\hline \multirow{2}{*}{ Bulanık } & Adet & 85 & 18 & 103 & 3 & 0 & 0 & 0 & 3 \\
\hline & $\%$ & 82.5 & 17.5 & 100 & 100 & 0 & 0 & 0 & 100 \\
\hline \multirow{2}{*}{ Hasköy } & Adet & 17 & 1 & 18 & - & - & - & - & - \\
\hline & $\%$ & 94.4 & 5.6 & 100 & - & - & - & - & - \\
\hline \multirow{2}{*}{ Korkut } & Adet & 24 & 0 & 24 & - & - & - & - & - \\
\hline & $\%$ & 100 & 0 & 100 & - & - & - & - & - \\
\hline \multirow{2}{*}{ Varto } & Adet & 44 & 8 & 52 & 5 & 9 & 6 & 4 & 24 \\
\hline & $\%$ & 84.6 & 15.4 & 100 & 20.8 & 37.5 & 25 & 16.4 & 100 \\
\hline \multirow{2}{*}{ Toplam } & Adet & 285 & 45 & 330 & 14 & 9 & 6 & 3 & 33 \\
\hline & $\%$ & 86.4 & 13.6 & 100 & 42.4 & 27.3 & 18.2 & 12.1 & 100 \\
\hline
\end{tabular}

$* * \mathrm{p}<0.01$

İşletmelerin büyük kısmı (\%82.6) inekleri kuruya çıkartmaktadır. Kuruya çıkarmayan işletmeler en fazla (\%25) yerli ve melez ırkın yetiştirildiği Bulanık ilçesinde bulunmakta ve bunu \%23.1 oranıla il merkezi izlemektedir (Çizelge 6). Mevki ile kuruya çıkarma arasındaki ilişki önemli $\quad(p<0.05)$ bulunmuştur. Genel olarak işletmelerin \%55.8'i inekleri 60 gün kuruya çıkartırken, bu oran kültür ırkının yoğun olduğu Korkut ilçesindeki işletmelerde \%70.8'e yükselmiştir. Hasköy ilçesinde yoğun olarak melez ve kültür ırkı yetiştirilmesine rağmen, \%61.6 oranında ineklerin 60 günden fazla kuruya çıkartılması dikkat çekici bulunmuştur. Mevki ile kuruda kalma süresi arasındaki ilişki çok önemli $(\mathrm{p}<0.01)$ bulunmuştur.

Muş ilinde yapılan önceki bir araştırmada, yetiştiricilerin \%46.0'sının inekleri sütten kendiliğinden kesilene kadar sağdıklarını, \%38.7'si de doğumuna 2 ay kala ineklerini kuruya çıkardıklarını bildirmişlerdir (Şeker ve ark., 2012). Araştırıcılar, kuruya çıkarma konusunda yetiştiricilerin çok dikkatli olmadıklarını, kuruya çıkarmanın gerekliliklerini tam olarak bilmediklerini ve sütü geçime katkı amaçlı olarak değerlendirdikleri için, mümkün olan son ana kadar ineklerini sağdıklarını düşündüklerini bildirmektedir. Bu araştırmada ise, Şeker ve ark. (2012)'nın aksine yetiştiricilerin ineklerini daha fazla kuruya çıkardıkları tespit edilmiştir. Bu durumun il genelinde işletmelerde yerli ırkın yoğun olarak yetiştirilmesinden ve yerli rrkın sağım sürelerinin diğer ırklara göre daha kısa olmasından kaynaklandığı düşünülmektedir. Birçok işletmeci yerli ırkları kendiliğinde kuruya çıkana kadar sağdıklarını beyan etmişlerdir.

Diyarbakır ilinde yapılan çalışmada süt sığırcılığı işletmelerinin \%54'ü iki, \%30’u üç ay süreyle inekleri kuruya ayırdığı, \%16'sının ise inekleri doğumdan bir sonraki doğuma kadar hiç kuruya ayırmadığ tespit edilmiştir (Tutkun ve ark., 2014). 
Çizelge 6. Kuruya çıkarma ve kuruda kalma süresinin mevkiye göre değişimi

\begin{tabular}{|c|c|c|c|c|c|c|c|c|c|c|}
\hline \multirow{2}{*}{ Mevki } & & \multicolumn{2}{|c|}{ Kuruya çıkarma* } & \multirow{2}{*}{ Toplam } & \multicolumn{5}{|c|}{ Kuruda kalma süresi** } & \multirow{2}{*}{ Toplam } \\
\hline & & Evet & Hayır & & $30 \geq$ & $31-59$ & 60 & $61-89$ & $90+$ & \\
\hline \multirow{2}{*}{ Merkez } & Adet & 40 & 12 & 52 & 3 & 1 & 24 & 2 & 10 & 40 \\
\hline & $\%$ & 76.9 & 23.1 & 100.0 & 7.5 & 2.5 & 60.0 & 5.0 & 25.0 & 100.0 \\
\hline \multirow{2}{*}{ Malazgirt } & Adet & 71 & 10 & 81 & 7 & 4 & 37 & 7 & 16 & 71 \\
\hline & $\%$ & 87.7 & 12.3 & 100.0 & 9.9 & 5.6 & 52.1 & 9.9 & 22.5 & 100.0 \\
\hline \multirow{2}{*}{ Bulanık } & Adet & 78 & 26 & 104 & 7 & 18 & 38 & 10 & 2 & 75 \\
\hline & $\%$ & 75.0 & 25.0 & 100.0 & 9.3 & 24.0 & 50.7 & 13.3 & 2.7 & 100.0 \\
\hline \multirow{2}{*}{ Hasköy } & Adet & 16 & 2 & 18 & 0 & 3 & 2 & 4 & 4 & 13 \\
\hline & $\%$ & 88.9 & 11.1 & 100.0 & 0.0 & 23.1 & 15.4 & 30.8 & 30.8 & 100.0 \\
\hline \multirow{2}{*}{ Korkut } & Adet & 24 & 0 & 24 & 0 & 7 & 17 & 0 & 0 & 24 \\
\hline & $\%$ & 100.0 & 0.0 & 100.0 & 0.0 & 29.2 & 70.8 & 0.0 & 0.0 & 100.0 \\
\hline \multirow{2}{*}{ Varto } & Adet & 47 & 8 & 55 & 0 & 0 & 35 & 3 & 13 & 51 \\
\hline & $\%$ & 85.5 & 14.5 & 100.0 & 0.0 & 0.0 & 68.6 & 5.9 & 25.5 & 100.0 \\
\hline \multirow{2}{*}{ Toplam } & Adet & 276 & 58 & 334 & 17 & 33 & 153 & 26 & 45 & 274 \\
\hline & $\%$ & 82.6 & 17.4 & 100.0 & 6.2 & 12.0 & 55.8 & 9.5 & 16.4 & 100.0 \\
\hline
\end{tabular}

${ }^{*} \mathrm{p}<0.05 * * \mathrm{p}<0.01$

Kaygısız ve ark. (2008) işletmelerde ineklerin \%59'unun doğuma iki ay kalana kadar, 25’inin sütten kesilene kadar sağıldığını tespit etmişlerdir. İşletmecilerin \%16'sı ise ineklerin zaten doğumdan iki ay önce kendiliğinden kuruya çıktığını ifade etmişlerdir. Bu araştırmada bulunan değer, Tutkun ve ark. (2014) ve Kaygısız ve ark. (2008)'nın bildirdiği değerler ile benzerlik göstermektedir.

İl genelindeki işletmelerde sağım \%65.4 oranında el ile ve \%34.4 oranında makine ile yapılmaktadır (Çizelge 7). İl merkezi, Hasköy ve Korkut ilçelerindeki işletmelerin \%50'sinden fazlasında makinalı sağım yapılmaktadır. En fazla el ile sağımın yapıldığı işletmeler Bulanık ve Varto ilçesinde bulunmaktadır. Yerli ve melez ırkı sığırların en fazla yetiştirildiği işletmelerin bu iki ilçedeki işletmelerde olduğu çizelge 1 'de görülmektedir. Mevki ile sağım şekli ve sayısı arasındaki ilişki çok önemli $(\mathrm{p}<0.01)$ bulunmuştur.

Çizelge 7. Sağım şekli ve sağım sayısının mevkiye göre değişimi

\begin{tabular}{|c|c|c|c|c|c|c|c|}
\hline \multirow{2}{*}{ Mevki } & & \multicolumn{2}{|c|}{ Sağım şekli** } & \multirow{2}{*}{ Toplam } & \multicolumn{2}{|c|}{ Sağım sayısı** } & \multirow{2}{*}{-Toplam } \\
\hline & & Elle & Makinalı & & Bir kez & İki kez & \\
\hline \multirow{2}{*}{ Merkez } & Adet & 26 & 28 & 54 & 8 & 46 & 54 \\
\hline & $\%$ & 48.1 & 51.9 & 100.0 & 14.8 & 85.2 & 100.0 \\
\hline \multirow{2}{*}{ Malazgirt } & Adet & 50 & 32 & 82 & 9 & 73 & 82 \\
\hline & $\%$ & 61.0 & 39.0 & 100.0 & 11.0 & 89.0 & 100.0 \\
\hline \multirow{2}{*}{ Bulanık } & Adet & 88 & 15 & 103 & 25 & 76 & 101 \\
\hline & $\%$ & 85.4 & 14.6 & 100.0 & 24.8 & 75.2 & 100.0 \\
\hline \multirow{2}{*}{ Hasköy } & Adet & 9 & 11 & 20 & 1 & 19 & 20 \\
\hline & $\%$ & 45.0 & 55.0 & 100.0 & 5.0 & 95.0 & 100.0 \\
\hline \multirow{2}{*}{ Korkut } & Adet & 9 & 15 & 24 & 0 & 24 & 24 \\
\hline & $\%$ & 37.5 & 62.5 & 100.0 & 0.0 & 100.0 & 100.0 \\
\hline \multirow{2}{*}{ Varto } & Adet & 39 & 16 & 55 & 10 & 45 & 55 \\
\hline & $\%$ & 70.9 & 29.1 & 100.0 & 18.2 & 81.8 & 100.0 \\
\hline \multirow{2}{*}{ Toplam } & Adet & 221 & 117 & 338 & 53 & 283 & 336 \\
\hline & $\%$ & 65.4 & 34.6 & 100.0 & 15.8 & 84.2 & 100.0 \\
\hline
\end{tabular}

$* * \mathrm{p}<0.01$

Farklı illerde yapılan araştırmalarda, işletmelerde çalışma ile benzer şekilde elle sağımın yaygın olarak yapıldığı görülmektedir. Buna göre, Van'da \%96.5 (Bakır, 2002); Erzincan ili Çayırlı ilçesinde \%81.0 (Özyürek ve ark., 2014); Kars ilinde \%78.4 (Demir ve ark., 2014) ve Erzurum ili Hınıs ilçesinde işletmelerin \%89.0 (Koçyiğit ve ark., 2016) oranlarında sağımın elle yapıldığı bildirilmektedir. Tutkun ve ark. (2017)
Diyarbakır ilindeki işletmelerin \%71'inde sağımın elle ve \%29'unda ise makine ile; Koçyiğit ve ark. (2017) Erzurum ili Narman ilçesinde \%78.8 oranında elle, \%20.7'sinde seyyar sağım makinesiyle çok düşük oranda (\%0.5) ise ayrı sağım ünitelerinde sağım yapıldığını bildirmişlerdir.

Mevcut araştırmada il genelinde \%84.2 oranında 
günde iki sağım yapılırken, yerli ırkın yoğun yetiştirildiği ilçelerde günde bir sağımın yapıldığı tespit edilmiştir (Çizelge 7). Mevki bazında ise, günde tek sağım yapan işletmeler en fazla Bulanık ilçesinde bulunmaktadır. Bu durumun ilçede yetiştirilen yerli irkların verimlerinin düşük olmasından kaynaklandığ̊ düşünülmektedir. Mevki ile sağım sayısı arasındaki ilişki çok önemli $\quad(p<0.01)$ bulunmuştur.

Benzer araştırmalarda ise makine ile sağım yapan işletmelerin oranını Kum (2006) \%98, Soyak ve ark. (2007) \%93, Tatar (2007) \%93 ve Önal ve Özder (2008) $\% 100$; Aksoy ve ark. (2014) birliğe üye olan işletmelerde \%88.7 ve olmayanlarda \%50 olarak bu çalışmadan daha yüksek oranda bildirmişlerdir.

Tutkun ve ark. (2017) Diyarbakır ilindeki işletmelerde genellikle sağımın sabah ve akşam olmak üzere günde $2 \mathrm{kez}$ yapıldığını, çok az sayıdaki işletmede günde 3 kez sağım yapıldığını bildirmektedir. İncelenen işletmelerin, \%96'sı günde $2 \mathrm{kez}, \% 4$ 'ü ise $3 \mathrm{kez}$ sağım yaptığ tespit edilmiştir. İşletmelerin \%71'inde sağım elle yapilırken, işletmelerin \%29'unda ise makineli sağımın yapıldığı belirlenmiştir.

Süt sığırcılığ işletmelerinde meme sağ lı̆̆ı ve sağım hijyeni, hem elde edilen sütün kalitesi ve güvenirliği açısından hem de tüketicilerin sağlığı açısından büyük önem arz etmektedir. Genel olarak işletmelerde sağım öncesi meme yıkanma oranının \%54 olduğu, meme yıkamayan işletmelerin oranının ise \%46 olduğu belirlenmiştir (Çizelge 8). Sağım öncesi meme temizliğinin yapılma oranının kültür ırkı yetiştiren işletmelerde yerli ve melez ırkların yoğun yetiştirildiği işletmelere göre daha yüksek olduğu görülmektedir. Buna göre, meme temizliği kültür ırkı yetiştiren işletmelerde diğer işletmelere göre hem daha yüksek oranda olup, hem de daha hassas şekilde uygulandığı tespit edilmiştir. İl genelinde sağım öncesi meme temizliği uygulama oranını yükseltmek için, yetiştiricilere verilecek eğitimlerde sağım öncesi meme temizliği ve hijyeni konusuna daha fazla önem verilmesi gerekmektedir. Mevki ile meme yıkama ve daldırma yapma arasındaki ilişki çok önemli $(p<0.01)$ bulunmuştur.

Çizelge 8. Sağım öncesi meme yıkama ve daldırma yapmanın mevkiye göre değişimi

\begin{tabular}{|c|c|c|c|c|c|c|c|}
\hline \multirow{2}{*}{ Mevki } & & \multicolumn{2}{|c|}{ Meme yıkama** } & \multirow{2}{*}{ Toplam } & \multicolumn{2}{|c|}{ Daldırma yapma** } & \multirow{2}{*}{ Toplam } \\
\hline & & Evet & Hayır & & Evet & Hayır & \\
\hline \multirow{2}{*}{ Merkez } & Adet & 34 & 20 & 54 & 13 & 41 & 54 \\
\hline & $\%$ & 63.0 & 37.0 & 100.0 & 24.1 & 75.9 & 100.0 \\
\hline \multirow{2}{*}{ Malazgirt } & Adet & 43 & 39 & 82 & 20 & 62 & 82 \\
\hline & $\%$ & 52.4 & 47.6 & 100.0 & 24.4 & 75.6 & 100.0 \\
\hline \multirow{2}{*}{ Bulanık } & Adet & 40 & 64 & 104 & 35 & 69 & 104 \\
\hline & $\%$ & 38.5 & 61.5 & 100.0 & 33.7 & 66.3 & 100.0 \\
\hline \multirow{2}{*}{ Hasköy } & Adet & 12 & 8 & 20 & 12 & 8 & 20 \\
\hline & $\%$ & 60.0 & 40.0 & 100.0 & 60.0 & 40.0 & 100.0 \\
\hline \multirow{2}{*}{ Korkut } & Adet & 19 & 5 & 24 & 16 & 8 & 24 \\
\hline & $\%$ & 79.2 & 20.8 & 100.0 & 66.7 & 33.3 & 100.0 \\
\hline \multirow{2}{*}{ Varto } & Adet & 35 & 20 & 55 & 13 & 42 & 55 \\
\hline & $\%$ & 63.6 & 36.4 & 100.0 & 23.6 & 76.4 & 100.0 \\
\hline & Adet & 183 & 156 & 339 & 109 & 230 & 339 \\
\hline Toplam & $\%$ & 54.0 & 46.0 & 100.0 & 32.2 & 67.8 & 100.0 \\
\hline
\end{tabular}

$* * \mathrm{p}<0.01$

İ genelinde sağım sonrası daldırma yapan işletmelerin oranı \%32.2 iken, daldırma yapmayanların oranı \%67.8 olarak belirlenmiştir. Kültür ırkının yoğun olduğu Korkut ve Hasköy gibi işletmelerde sağım sonrası daldırma yapanların oranı diğer ilçelere göre daha yüksek bulunmuştur. Önal ve Özder (2008) işletmelerin \% 19.3'ünün mastitisten korunmak ya da meme sağlığını korumak amacıyla sağımdan sonra daldırma yaptıklarını bildirmiştir.

Daş ve ark. (2014) Bingöl'de yetiştiricilerin \%66.3 oranında her sağımdan önce meme temizliği yaptığını ve diğerlerinin ise \%19.4'ü bazen, \%12.0'ı günde bir defa meme temizliği yaptıklarını bildirmektedir. Diyarbakır ilinde yapılan araştırmada işletmelerin \%64'ünde sağım öncesi ve sonrası meme temizliği yapılırken, bu işletmelerin \%36'sında meme temizliğinin yapılmadığı tespit edilmiştir. Meme temizliği yapan işletmelerin \%55'inde temizlik sırasında dezenfektan madde kullandığ kullanılmadığı temizliğin sadece su ile yapıldığı bildirilmiştir (Tutkun ve ark., 2017).

Farklı illerde yapılan araştırmalarda sağım öncesi meme temizliği yapan işletmelerin oranını; Soyak ve ark. (2007) Tekirdağ ilinde \%96.0; Tatar (2007) Ankara'da \%98.4 ve Aksaray'da \%96.5; Kaygisız ve ark. (2008) Kahramanmaraş'ta \%78.0; Demir ve ark. (2014) Kars ilinde \%52.5; Özyürek ve ark. (2014) Erzincan ili Çayırlı ilçesinde \%93.3 ve Savaş ve Yenice (2016) Rize'de \%13.4; Koçyiğit ve ark. (2016) Erzurum ili Hınıs ilçesinde \%85 ve Koçyiğit ve ark. (2017) 
Erzurum ili Narman ilçesinde \%54.4 olarak bildirmişlerdir.

İşletmelerde üretilen sütün hane halkı tarafından tüketilme oranı \%10-\%100 olmak üzere geniş bir değişim göstermektedir (Çizelge 9). Hane halkı üretilen sütü hem evin günlük ihtiyacı olan peynir, yoğurt ve tereyağına işlemekte hem de bu ürünlerin fazlasinı satarak ev ekonomisine katkıda bulunmaktadır. Hayvan sayısı az olan işletmelerde üretilen sütün tamamına yakını hane halkı tarafından ev ihtiyacı olarak kullanılırken, hayvan sayısı fazla olan işletmelerde üretilen sütün \%80'den fazlası satılmaktadır. Mevki ile üretilen sütün işletmede tüketimi ve satışının arasındaki ilişki önemli $(\mathrm{p}<0.05$, $\mathrm{p}<0.01$ ) bulunmuştur.

Çizelge 9. Üretilen sütün işletmede tüketimi ve satışının mevkiye göre değişimi

\begin{tabular}{|c|c|c|c|c|c|c|c|c|c|c|c|}
\hline \multirow{2}{*}{ Mevki } & & \multicolumn{4}{|c|}{ Tüketim (\%)** } & \multirow{2}{*}{ Toplam } & \multicolumn{4}{|c|}{ Süt satış (\%)* } & \multirow{2}{*}{ Toplam } \\
\hline & & $10-15$ & $20-25$ & $30-50$ & $60-100$ & & $<30$ & $31-50$ & $51-75$ & $76>$ & \\
\hline \multirow{2}{*}{ Merkez } & Adet & 4 & 12 & 21 & 12 & 49 & 2 & 16 & 6 & 17 & 41 \\
\hline & $\%$ & 8.2 & 24.5 & 42.9 & 24.5 & 100.0 & 4.9 & 39.0 & 14.6 & 41.5 & 100.0 \\
\hline \multirow{2}{*}{ Malazgirt } & Adet & 0 & 25 & 26 & 22 & 73 & 1 & 9 & 11 & 8 & 29 \\
\hline & $\%$ & 0.0 & 34.2 & 35.6 & 30.1 & 100.0 & 3.4 & 31.0 & 37.9 & 27.6 & 100.0 \\
\hline \multirow{2}{*}{ Bulanık } & Adet & 24 & 35 & 21 & 17 & 97 & 8 & 13 & 2 & 5 & 28 \\
\hline & $\%$ & 24.7 & 36.1 & 21.6 & 17.5 & 100.0 & 28.6 & 46.4 & 7.1 & 17.9 & 100.0 \\
\hline \multirow{2}{*}{ Hasköy } & Adet & 2 & 8 & 1 & 4 & 15 & 0 & 2 & 0 & 3 & 5 \\
\hline & $\%$ & 13.3 & 53.3 & 6.7 & 26.7 & 100.0 & 0.0 & 40.0 & 0.0 & 60.0 & 100.0 \\
\hline \multirow{2}{*}{ Korkut } & Adet & 16 & 1 & 4 & 3 & 24 & 3 & 4 & 3 & 1 & 11 \\
\hline & $\%$ & 66.7 & 4.2 & 16.7 & 12.5 & 100.0 & 27.3 & 36.4 & 27.3 & 9.1 & 100.0 \\
\hline \multirow{2}{*}{ Varto } & Adet & 8 & 17 & 11 & 17 & 53 & 3 & 6 & 4 & 17 & 30 \\
\hline & $\%$ & 15.1 & 32.1 & 20.8 & 32.1 & 100.0 & 10.0 & 20.0 & 13.3 & 56.7 & 100.0 \\
\hline \multirow{2}{*}{ Toplam } & Adet & 54 & 98 & 84 & 75 & 311 & 17 & 50 & 26 & 51 & 144 \\
\hline & $\%$ & 40.5 & 25.7 & 4.8 & 28.9 & 100.0 & 11.8 & 34.7 & 18.1 & 35.4 & 100.0 \\
\hline
\end{tabular}

$* p<0.05 * * p<0.01$

Özyürek ve ark. (2014)'ı işletmelerin \%64'ünün sağdıkları sütü kendilerinin değerlendirdiğini, sadece \%10'unun sütü sattığını, geri kalan işletmelerin ise sütü sadece buză̆ıya verdiklerini bildirmişlerdir. Tümer ve Kumbasaroğlu (2008) Tokat ili Turhal ilçesinde yaptıkları araştırmada, I. grupta günlük üretilen sütün \%3.5'i evde tüketilirken, \%96.5'i kooperatife satıldığını ve II. grup işletmelerde ise günlük üretilen sütün \%12.7'si evde tüketilirken \%87.3’ü köy toplayıcılarına satıldığını bildirmişlerdir.

İşletmelerde üretilen süt peynir, yoğurt ve tereyağ şeklinde ürüne dönüştürülmektedir. İl genelinde işletmelerin \%70.5’i üretilen sütü tek ürün şeklinde değil, peynir-yoğurt-tereyağı kombinasyonu olarak değerlendirmektedir (Çizelge 10). Mevki bazında ise kültür ırkının yoğun yetiştirildiği Korkut ilçesindeki işletmecilerin \%75'i diğerlerinin aksine sütü peyniryoğurt kombinasyonu şeklinde değerlendirdiği tespit edilmiştir. Mevki ile süt ürünleri arasındaki ilişki çok önemli $(\mathrm{p}<0.01)$ bulunmuştur.

Farklı araştırmalarda işletmelerde üretilen sütün tüketim ve satış kombinasyonlarını Giresun'da Tugay ve Bakır (2009) genellikle aile-yağ-yoğurt-peynir-süt (\%41.6) ve aile-satış-yağ-yoğurt-peynir-süt (\%34) şeklinde yapıldığını bildirmişlerdir. Tutkun ve ark., (2017)'ı Diyarbakır ve ilçelerinde işletmelerin büyük bölümünün sütü peynir, yoğurt ve tereyağı gibi farklı ürünlere işleyerek değerlendirdiğini bildirmişlerdir. Boz (2013) tarafindan Doğu Akdeniz bölgesinde yapılan araştırmada, işletmecilerin \%18'inin ürettiği sütü peynir ya da tereyağı yaparak sattığı belirlenmiştir. Tümer ve Kumbasaroğlu (2008) Tokat ili Turhal ilçesinde işletmelerde elde edilen sütün, tereyağı, peynir ve çökelek gibi süt ürünlerine dönüştürülerek semt pazarlarında satıldığını bildirmektedir.

Genel olarak, işletmelerde sağım öncesi meme temizliği ve sağım sonrası daldırma uygulamasının yetersiz olması hem inek sağlığına hem de sağım sonrası sütün temiz ve kaliteli elde edilememesine neden olmaktadır. İncelenen tüm özellikler için işletmeler arasında önemli farklılıklar gözlenmiştir. $\mathrm{Bu}$ farklılıkların oluşmasında, işletmede yetiştirilen sığırların ırkı başta olmak üzere işletmelerin kendi imkanları, yararlandığ önemli rol oynadığı düşünülmektedir. İşletmelerde süt verimini artırmak için, işletmenin barınak dahil alt yapısının iyileştirilmesi, kültür ırklarının oranının artırılması, mera imkanı ve mera ot kalitesinin artırılması, hayvancılığın sadece meraya dayalı yapılmaması ve yetiştiricilerin teknik bilgi düzeylerinin artırılması önerilmektedir.

\section{SONUÇ ve ÖNERILLER}

$\mathrm{Bu}$ çalışmada Muş il merkezi ve ilçelerindeki süt sığırcılığı işletmelerinin süt verimiyle ilgili bazı özelliklere ait uygulamalar incelenmiştir. 
Çizelge 10. İşletmede üretilen ürünlerin mevkiye göre değişimi

\begin{tabular}{|c|c|c|c|c|c|c|}
\hline \multirow{2}{*}{ Mevki } & & \multirow[b]{2}{*}{ Peynir } & \multicolumn{3}{|c|}{ Süt ürünleri** } & \multirow[b]{2}{*}{ Toplam } \\
\hline & & & Yoğurt & Peynir -Yoğurt & Peynir-Yoğurt-Tereyağı & \\
\hline \multirow{3}{*}{ Merkez } & Adet & 2 & 8 & 13 & 26 & 49 \\
\hline & $\%$ & 4.1 & 16.3 & 26.5 & 53.1 & 100.0 \\
\hline & Adet & 12 & 6 & 6 & 58 & 82 \\
\hline \multirow[t]{2}{*}{ Malazgirt } & $\%$ & 14.6 & 7.3 & 7.3 & 70.7 & 100.0 \\
\hline & Adet & 8 & 1 & 1 & 90 & 100 \\
\hline \multirow[t]{2}{*}{ Bulanık } & $\%$ & 8.0 & 1.0 & 1.0 & 90.0 & 100.0 \\
\hline & Adet & 1 & 3 & 7 & 8 & 19 \\
\hline \multirow[t]{2}{*}{ Hasköy } & $\%$ & 5.3 & 15.8 & 36.8 & 42.1 & 100.0 \\
\hline & Adet & 4 & 0 & 18 & 2 & 24 \\
\hline \multirow[t]{2}{*}{ Korkut } & $\%$ & 16.7 & 0.0 & 75.0 & 8.3 & 100.0 \\
\hline & Adet & 4 & 2 & 1 & 48 & 55 \\
\hline Varto & $\%$ & 7.3 & 3.6 & 1.8 & 87.3 & 100.0 \\
\hline \multirow{2}{*}{ Toplam } & Adet & 31 & 20 & 46 & 232 & 329 \\
\hline & $\%$ & 9.4 & 6.1 & 14.0 & 70.5 & 100.0 \\
\hline
\end{tabular}

$* * \mathrm{p}<0.01$

Il genelinde işletmelerde yetiştirilen sığırların çoğunlukla yerli ve melez irklardan oluştuğu ve ilçe bazında önemli farklılıklar olduğu görülmüştür. $\mathrm{Bu}$ farklılıklar incelenen özellikler bakımından işletmelerde değişik sonuçların ortaya çıkmasını sağlamıştır. Muş ilinde yapılan önceki araştırmaya göre, il genelindeki işletmelerde yetiştirilen kültür ırkı sığır sayısında artış bulunmuştur. Bu durum süt sığırcılığını desteklemek ve geliştirmek için yapılan çalışmalarının işletmelere olumlu yansıdığını göstermektedir.

İl genelinde sığırların sağım süresi ortalama 7.4 ay iken, kültür ırkı olan ilçelerdeki işletmelerde bu değer daha yüksek bulunmuştur. Sığırcılıkta sağım süresinin normalde 10 ay olması istenirken, araştırmada bulunan değerin istenenden düşük olması işletmelerin gelirlerinin de düşmesine neden olmaktadır. Bu durumun hem işletmelerde yetiştirilen ırkların yerli ve melez ağırlıklı olmasından hem de bölgenin iklim şartlarının sonucu sıcaklık stresi ve yem bitkilerinin yeşil vejetasyon döneminin kısalığından kaynaklandığı düşünülmektedir. İşletmelerdeki günlük ve yıllık süt verimi işletmenin bulunduğu mevkiye, yetiştirilen ırkların karakterine ve işletmelerin imkanına göre geniş bir varyasyon göstermiştir. $\mathrm{Bu}$ bağlamda, işletmelerin sadece $\% 40.7$ 'si ineklerden alınan süt veriminin yeterli olduğunu bildirmesi, ırk-imkan gerekçesini doğrulamaktadır.

\section{KAYNAKLAR}

Aksoy A, Güler İO, Terin M 2014. Erzurum ili damızlık sığır yetiştiricileri birliğine üye olan ve olmayan üreticilerin belirli özellikler açısından karşılaştırılması. GOP Ziraat Fakültesi Dergisi, 31(3):82-90.
Anonim 2019. Hayvancılık İstatistikleri. Türkvet kayıtları. /Erişim, 03.03.2019.

Bakan Ö, Aydın R 2016. Ağrı ili süt sığırcılığı işletmelerinin sosyo-ekonomik özellikleri. Atatürk Üniv. Ziraat Fakültesi Dergisi, 47(2):113-122.

Bakır G 2002. Van ilindeki özel süt sı̆̆ırcılığı işletmelerinde tercih edilen kültür ırkları. YYÜ. Tarım Bilimleri Dergisi, 12(2):11-20.

Boz İ 2013. Doğu Akdeniz Bölgesi'nde süt sığırcılığı yapan işletmelerin yapısı, sorunları ve çözüm önerileri. KSÜ. Doğa Bilimleri Dergisi, 16(1):24-32.

Cochran WG 1977. Sampling techniques (3rd Edition). John Wiley\&Sons. New York. https://www. academia.edu/29684662/ pdf. (Erişim: 14.01.2019).

Çoban O, Laçin E, Sabuncuoğlu N, Genç M 2013. Production and health parameters in cattle herds: A Survey from Eastern Turkey. Journal Animal and Plant Sciences, 23(6):1572-1577.

Daş A, Inci H, Karakaya E, Şengül AY 2014. Bingöl ili damızlık sığır yetiştiricileri birliğine bağlı sığırcılık işletmelerinin mevcut durumu. Türk Tarım ve Doğa Bilimleri Dergisi, 1(3):421-429.

Demir P, Aral S 2009. Kars ilinde faaliyet gösteren süt sığırcılık işletmelerinin karşılaştıkları sorunlar ve çözüm önerileri. Veteriner Hekimler Derneği Dergisi, 80: 17-22.

Düzgüneş O, Kesici T, Gürbüz F 1983. İstatistik Metodları I. Ankara Üniv. Ziraat Fak. Yay. 229.

Güler O, Aydın R, Yanar M, Diler A, Koçyiğit R, Avcı M 2016. Erzurum ili Hınıs ilçesi sığırcılık işletmelerinin sosyo-ekonomik yapısı. Alınteri Zirai Bilimler Dergisi, 30(1):27-37.

Kaygısız A, Tümer R, Orhan H, Vanlı Y 2008. Kahramanmaraş bölgesi süt sığırcılık işletmelerinin yapısal özellikleri: 1. Yetiştirme uygulamaları. SDÜ Ziraat Fakültesi Dergisi, 
3(2):23-31.

Koçyiğit R, Diler A, Yanar M, Güler O, Aydın R, Avcı M 2016. Süt sığırcılı̆̆ı işletmelerinde hayvan sağllı̆̆l, veteriner sağlık hizmetleri ve yetiştirici memnuniyeti: Erzurum ili Hınıs ilçesi örneği. Türk Tarım ve Doğa Bilimleri Dergisi, 3(1):24-32.

Koçyiğit R,Yanar M, Diler A, Güler O, Aydın R 2017. Erzurum İli Narman İlçesindeki sığırcılık işletmelerinde uygulanan sağım yönetimi üzerine bir araştırma. Alınteri Zirai Bilimler Dergisi, $32(2): 45-54$.

Kum G 2006. Antalya ili Holstein ırkı damızlık sığır yetiştiricileri birliğine üye işletmelerin mevcut durumu, Besleme alışkanlıkları ve sorunları. YYÜ Fen Bilimleri Enstitüsü, Zootekni Ana Bilim Dalı, Yüksek Lisans Tezi, 67s.

Önal AR, Özder M 2008. Edirne İli damızlık sığır yetiştiricileri birliğine üye işletmelerin yapısal özellikleri. Tekirdağ Ziraat Fakültesi Dergisi, 5 (2):197-203.

Öztürk D, Karkacier O 2008. Süt sığırcılığı yapan işletmelerin ekonomik analizi (Tokat İli Yeşilyurt İlçesi Örneği). GOP Ziraat Fakültesi Dergisi, 25 (1):15-22.

Özyürek S, Koçyiğit R, Tüzemen N 2014. Erzincan İlinde süt sığırcılığı yapan işletmelerin yapısal özellikleri: Çayırlı İlçesi örneği. Tekirdağ Ziraat Fakültesi Dergisi, 11(3):19-26.

Savaş S, Yenice G 2016. Rize ilinde yapılan süt siğırcılığının mevcut durumunun araştırılması. Atatürk Üniv. Vet. Bilimleri Dergisi, 11(1):74-83.

Soyak A, Soysal MI, Gürcan EK (2007) Tekirdağ ilindeki süt sığırcılığı işletmelerinin yapısal özellikleri ve bu işletmelerdeki siyah alaca süt sığırlarının çeşitli morfolojik özellikleri üzerine bir araştırma. Tekirdağ Ziraat Fakültesi Dergisi, 4(3):297-305.

Şeker İ, Tasalı H, Güler H 2012. Muş ilinde sığır yetiştiriciliği yapılan işletmelerin yapısal özellikleri. FÜ. Sağ. Bil. Vet. Dergisi, 26(1): 9-16.

Tatar AM 2007. Ankara ve Aksaray damızlık sığır yetiştiricileri il birliklerine üye süt sığırı işletmelerinin yapısı ve sorunları. Ankara Üniversitesi Fen Bilimleri Enstitüsü, Zootekni Anabilim Dalı, Doktora Tezi, 97s

Tilki M, Sarı M, Aydın E, Işık S, Aksoy AR 2013. Kars ili sığır işletmelerinde barınakların mevcut durumu ve yetiştirici talepleri: I. Mevcut durum. Kafkas Üniv. Veteriner Fak. Dergisi, 19(1):109-116.

Tugay A, Bakır G 2009. Giresun yöresindeki süt sığırcılığı işletmelerinin yapısal özellikleri. Atatürk Üniv. Ziraat Fakültesi Dergisi, 40(1):37-47.

Tutkun M, Denli M, Sessiz A 2017. Diyarbakır ili süt sığgrıcılığı işletmelerinin yapısal durum analizi. Türk Tarım-Gıda Bilim ve Teknoloji Dergisi, 5(5):476-483.

Tümer E, Kumbasaroğlu H 2008. Tokat İli Turhal İlçesinde hayvan sigortası yaptıran ve yaptırmayan işletmelerde inek sütü maliyetlerinin hesaplanması. Atatürk Üniv. Ziraat Fakültesi Dergisi, 39 (2):187-194.

Yamane T 2006. Temel örnekleme yöntemleri. (Çeviri: Esin A, Bakır MA, Aydın C, Güzbüzsel E.) Literatür Yayınları: 53, İstanbul, 411s. 